\title{
Tuberculous optochiasmatic arachnoiditis and vision loss
}

Figure T2 coronal MRI

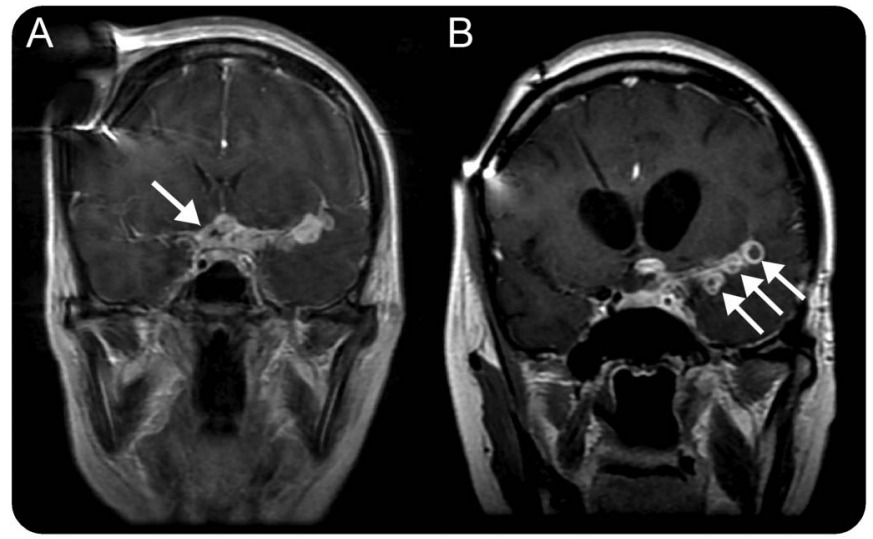

(A) Optochiasmatic arachnoiditis. (B) Tuberculomas.

A 24-year-old woman presented with a 1-week history of fever, vomiting, and gradual onset bilateral frontal headache. CSF was notable for lymphocytosis, high protein, and low glucose and lactate dehydrogenase, but acid-fast bacilli were only noted 1 month after initial sampling. The patient subsequently developed vision loss with no light perception bilaterally despite prompt antituberculous and steroid therapy. MRI revealed optochiasmatic arachnoiditis and tuberculomas (figure). Tuberculous meningitis has a propensity for the skull base, and is associated with high morbidity and mortality, causing visual impairment in $25 \%-27 \%$ of patients. ${ }^{1,2}$ Prompt recognition and initiation of antituberculous and steroid therapy is crucial.

Ru-ik Chee, MD, MSc, Marc J. Dinkin, $M D$

From Weill Cornell Medicine, New York, NY.

Author contributions: $\mathrm{Ru}$-ik Chee: conception and design, acquisition and assembly of data, analysis and interpretation of data, manuscript writing, final approval of manuscript, administrative support. Marc J. Dinkin: study concept and design, acquisition of data, analysis and interpretation of data, manuscript writing, final approval of manuscript.

Study funding: No targeted funding reported.

Disclosure: The authors report no disclosures relevant to the manuscript. Go to Neurology.org for full disclosures.

Correspondence to Dr. Chee: ruc9021@nyp.org

1. Garg RK, Paliwal V, Malhotra HS. Tuberculous optochiasmatic arachnoiditis: a devastating form of tuberculous meningitis. Expert Rev Anti Infect Ther 2011;9:719-729.

2. Sinha MK, Garg RK, Anuradha HK, et al. Vision impairment in tuberculous meningitis: predictors and prognosis. J Neurol Sci 2010;290:27-32. 


\title{
Neurology
}

\author{
Tuberculous optochiasmatic arachnoiditis and vision loss \\ Ru-ik Chee and Marc J. Dinkin \\ Neurology 2016;87;1845 \\ DOI 10.1212/WNL.0000000000003268
}

This information is current as of October 24, 2016

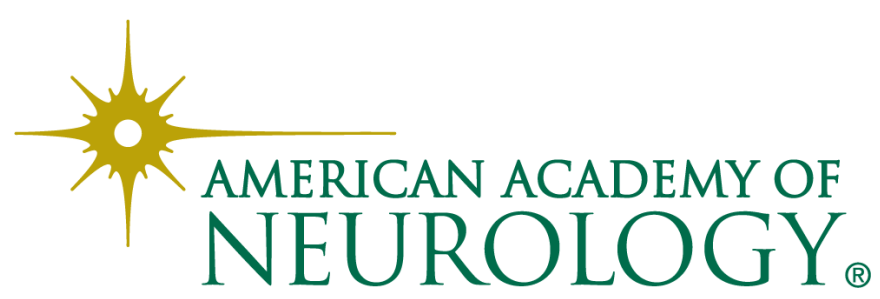




\section{Updated Information \& Services}

References

Citations

Subspecialty Collections

Errata

Permissions \& Licensing

\section{Reprints}

including high resolution figures, can be found at: http://n.neurology.org/content/87/17/1845.full

This article cites 2 articles, 0 of which you can access for free at: http://n.neurology.org/content/87/17/1845.full\#ref-list-1

This article has been cited by 3 HighWire-hosted articles: http://n.neurology.org/content/87/17/1845.full\#\#otherarticles

This article, along with others on similar topics, appears in the following collection(s):

All Neuro-ophthalmology

http://n.neurology.org/cgi/collection/all_neuroophthalmology

Bacterial infections

http://n.neurology.org/cgi/collection/bacterial_infections

Meningitis

http://n.neurology.org/cgi/collection/meningitis

Optic nerve

http://n.neurology.org/cgi/collection/optic_nerve

Visual loss

http://n.neurology.org/cgi/collection/visual_loss

An erratum has been published regarding this article. Please see next page or:

/content/88/16/1591.3.full.pdf

Information about reproducing this article in parts (figures,tables) or in its entirety can be found online at:

http://www.neurology.org/about/about_the_journal\#permissions

Information about ordering reprints can be found online:

http://n.neurology.org/subscribers/advertise

Neurology ${ }^{\circledR}$ is the official journal of the American Academy of Neurology. Published continuously since 1951, it is now a weekly with 48 issues per year. Copyright @ 2016 American Academy of Neurology. All rights reserved. Print ISSN: 0028-3878. Online ISSN: 1526-632X.

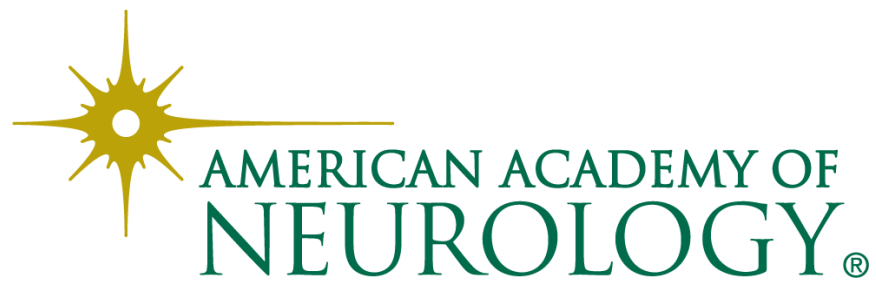


Editors' Note: In WriteClick this week, Kumfor et al. comment on the differences between brain reserve and cognitive reserve in reference to "Cognitive reserve in frontotemporal degeneration: Neuroanatomic and neuropsychological evidence." Authors Placek et al. agree that more research is required to better characterize both mechanisms. Malhotra et al. correctly comment that in the Neurolmage "Tuberculous optochiasmatic arachnoiditis and vision loss," T1-weighted postcontrast coronal images are shown rather than T2-weighted images, as labeled in the legend. A correction appears on page 1591.

-Megan Alcauskas, $M D$, and Robert C. Griggs, $M D$

\section{LETTER RE: COGNITIVE RESERVE IN}

FRONTOTEMPORAL DEGENERATION: NEUROANATOMIC AND NEUROPSYCHOLOGICAL EVIDENCE

Fiona Kumfor, Sydney, Australia; Cristian E. Leyton, Boston, MA; Olivier Piguet, Sydney, Australia: In the article by Placek et al. ${ }^{1}$, letter fluency was used as a proxy of executive function and as one of the tasks to assess cognitive reserve (CR). Letter fluency relies on multiple cognitive processes and, in such a diverse clinical sample, is unlikely to reflect a single neurocognitive process. These findings are therefore difficult to interpret.

Further, the results seem interpreted by conflating 2 distinct, but related, mechanisms: brain reserve (i.e., passive process where larger brains are less affected by damage than smaller brains) and CR (i.e., active use of compensatory processes to maintain function despite advancing neuropathology). ${ }^{2}$ Accordingly, larger brain volume appears supportive of greater brain reserve, whereas better letter fluency may reflect greater CR. These 2 mechanisms may help reconcile apparently contradictory findings in dementia, whereby higher CR is associated with shorter disease duration in Alzheimer disease $(\mathrm{AD}),{ }^{3}$ but longer duration in frontotemporal dementia. ${ }^{4}$ It is plausible that, in $\mathrm{AD}$, compensatory mechanisms can delay symptomatology, whereas, in frontotemporal dementia, brain reserve may be more important. Longitudinal studies that combine behavioral and neuroimaging data are likely to shed light on this important issue. ${ }^{5}$
1. Placek K, Massimo L, Olm C, et al. Cognitive reserve in frontotemporal degeneration: neuroanatomic and neuropsychological evidence. Neurology 2016;87:1813-1819.

2. Stern Y. Cognitive reserve. Neuropsychologia 2009;47: 2015-2028.

3. Stern Y. Cognitive reserve in ageing and Alzheimer's disease. Lancet Neurol 2012;11:1006-1012.

4. Massimo L, Zee J, Xie SX, et al. Occupational attainment influences survival in autopsy-confirmed frontotemporal degeneration. Neurology 2015;84:2070-2075.

5. Landin-Romero R, Kumfor F, Leyton CE, Irish M, Hodges JR, Piguet O. Disease-specific patterns of cortical and subcortical degeneration in a longitudinal study of Alzheimer's disease and behavioural-variant frontotemporal dementia. Neuroimage Epub 2016 Mar 21.

C) 2017 American Academy of Neurology

\section{AUTHOR RESPONSE: COGNITIVE RESERVE IN FRONTOTEMPORAL DEGENERATION: NEUROANATOMIC AND NEUROPSYCHOLOGICAL EVIDENCE}

Katerina Placek, Lauren Massimo, Murray Grossman, Corey T. McMillan, Philadelphia: Letter fluency is a verbally mediated measure of executive control and we agree that it is a complex task. In our study, we demonstrated in patients with frontotemporal degeneration (FTD) that higher cognitive reserve (CR) and higher frontal gray matter density are selectively associated with superior performance on letter fluency and not on the Boston Naming Test. ${ }^{1}$ Prior work demonstrated that inferior frontal gyrus and frontal lobe white matter support letter fluency task performance., ${ }^{2,3}$ Our observations converge with these prior demonstrations.

We agree that additional longitudinal studies are necessary to distinguish between active compensatory and passive brain reserve mechanisms. Our work, ${ }^{4}$ associating higher CR with early frontal atrophy and prolonged survival in autopsy-proven FTD, contrasts with observations in $\mathrm{AD}$ that show shorter survival in patients with higher CR and later frontal atrophy. ${ }^{5}$ While our imaging methods account for interindividual differences in intracranial volume, ${ }^{6}$ and control for differences in disease duration and age, we cannot rule out the possibility that individuals with higher $\mathrm{CR}$ are able to sustain cognitive function due to greater neuronal richness or frontal brain connectivity. Nonetheless, these 2 studies provided a valuable start to disentangling the mechanisms underlying $\mathrm{CR}$. 
1. Placek K, Massimo L, Olm C, et al. Cognitive reserve in frontotemporal degeneration: neuroanatomic and neuropsychological evidence. Neurology 2016;87:1813-1819.

2. Baldo JV, Schwartz S, Wilkins D, Dronkers NF. Role of frontal versus temporal cortex in verbal fluency as revealed by voxel-based lesion symptom mapping. J Int Neuropsychol Soc 2006;12:896-900.

3. Cook PA, McMillan DT, Avants BB, Peelle JE, Gee JC, Grossman M. Relating brain anatomy and cognitive ability using a multivariate multimodal framework. Neuroimage 2014;99:477-486.

4. Massimo L, Zee J, Xie SX, et al. Occupational attainment influences survival in autopsy-confirmed frontotemporal degeneration. Neurology 2015;84:2070-2075.

5. Stern Y. Cognitive reserve in ageing and Alzheimer's disease. Lancet Neurol 2012;11:1006-1012.

6. Klein A, Ghosh SS, Avants B, et al. Evaluation of volumebased and surface-based brain image registration methods. Neuroimage 2010;51:214-220.

(C) 2017 American Academy of Neurology

\section{LETTER RE: TUBERCULOUS OPTOCHIASMATIC ARACHNOIDITIS AND VISION LOSS}

Hardeep S. Malhotra, Neeraj Kumar, Ravindra Kumar Garg, Lucknow, India: The NeuroImage by Drs. Chee and Dinkin included T1-weighted gadolinium contrast coronal images instead of T2weighted sequences. The legend should be revised to include more details, such as having performed a shunt procedure, as evident from the image. ${ }^{1}$

1. Chee RI, Dinkin MJ. Tuberculous optochiasmatic arachnoiditis and vision loss. Neurology 2016;87:1845.

(c) 2017 American Academy of Neurology

\section{AUTHOR RESPONSE: TUBERCULOUS OPTOCHIASMATIC ARACHNOIDITIS AND VISION LOSS}

Marc J. Dinkin, Ru-Ik Chee, New York: We thank Malhotra et al. for pointing out that our NeuroImage was of $\mathrm{T} 1$ postcontrast coronal images, not $\mathrm{T} 2$, and apologize for the error. ${ }^{1}$

Malhotra et al. are also correct in observing a right-frontal ventriculoperitoneal shunt, which had been placed to treat hydrocephalus associated with tuberculous meningitis. Hydrocephalus is a common feature of this disease, occurring in up to $26 \%$ of adults and $90 \%$ of children, ${ }^{2,3}$ due to either an adhesive leptomeningitis in the basal cisterns (communicating) or obstruction of the aqueduct or fourth ventricle (noncommunicating). Shunting for tuberculous hydrocephalus demonstrated substantial clinical improvement in 7 children, 3 of whom had near complete recovery of vision after weeks of blindness, attributed to reduced compression on the ophthalmic arteries and optic apparatus by exudate and dilated ventricles. ${ }^{4}$

1. Chee RI, Dinkin MJ. Tuberculous optochiasmatic arachnoiditis and vision loss. Neurology 2016;87:1845.

2. Wasay M, Farooq S, Khowaja ZA, et al. Cerebral infarction and tuberculoma in central nervous system tuberculosis: frequency and prognostic implications. J Neurol Neurosurg Psychiatry 2014;85:1260-1264.

3. Schoeman J, Hewlett R, Donald P. MR of childhood tuberculous meningitis. Neuroradiology 1988;30:473477.

4. Bhagwati SN. Ventriculoatrial shunt in tuberculous meningitis with hydrocephalus. J Neurosurg 1971;35:309-313.

(C) 2017 American Academy of Neurology

\section{CORRECTION}

Tuberculous optochiasmatic arachnoiditis and vision loss

In the NeuroImage "Tuberculous optochiasmatic arachnoiditis and vision loss" by R.I. Chee and M.J. Dinkin, ${ }^{1}$ the image should have been labeled "T1 postcontrast coronal MRI" rather than "T2 coronal MRI." The authors regret the error.

\section{REFERENCE}

1. Chee RI, Dinkin MJ. Tuberculous optochiasmatic arachnoiditis and vision loss. Neurology 2016;87:1845. 